Marta Kruhlaya

Marcin Molenda

\title{
Migracje zarobkowe jako sposób na pozyskanie pracowników w latach 2009-2020
}

Labour migration as a way to recruit employees in the years 2009-2020

\section{Wstęp}

Przemieszczenie sięludności na świecie zdeterminowane jest przede wszystkim poziomem rozwoju gospodarczego danego kraju. W krajach rozwijających się istnieją duże nadwyżki siły roboczej, co powoduje, że wiele osób decyduje się na migracje zarobkowe, natomiast gospodarki państw rozwiniętych korzystają z napływu ludności, która zasila miejscowy rynek pracy. Szczególnie istotny jest napływ wykształconych oraz posiadających kwalifikacje pracowników, ponieważ kraje te pozyskują specjalistów w wybranej dziedzinie, nie ponosząc jednocześnie kosztów ich kształcenia. Dlatego celem niniejszego artykułu jest zaprezentowanie sytuacji na rynku pracy w Polsce w okresie 2009 rok - I kwartał $2020 \mathrm{roku}^{1}$, jak również przedstawienie migracji zarobkowych jako sposobu na uzupełnienie niedoboru pracowników na krajowym rynku pracy. Celowi podporządkowany jest układ pracy. W pierwszej części artykułu omówione będą zagadnienia dotyczące migracji zarobkowych oraz istotność zjawiska dla rozwoju przedsiębiorstw. Następnie zostaną przedstawione sytuacja na rynku pracy w Polsce, dane dotyczące zatrudnienia cudzoziemców w Polsce oraz wyniki badań własnych wśród polskich przedsiębiorców zatrudniających imigrantów.

Praca nie obejmuje okresu, kiedy wprowadzono w Polsce stan zagrożenie epidemicznego w związku z pandemią koronowirusa SARS-CoV-2, wywołującego chorobę COVID 19, i jej wpływu na rynek pracy. Zagadnienie te zostaną zbadane oraz zaprezentowane po ukazaniu się oficjalnych danych. 


\section{Migracje jako czynnik ksztattujący rynek pracy}

W literaturze przedmiotu migracja jest definiowana na różne sposoby w zależności od dziedziny naukowej. Samo słowo migracja pochodzi od łacińskiego wyrazu migratio, co oznacza „przesiedlenie się, wędrówka”. Uniwersalny słownik języka polskiego definiuje migrację jako przemieszczanie się ludności w obrębie kraju lub z jednego kraju do drugiego, najczęściej w poszukiwaniu lepszych warunków życia (Dubisz, 2003, s. 652). Definicję tę można uznać z jednej strony za uniwersalną, obejmującą różne typy migracji, natomiast z drugiej strony za budzącą wiele wątpliwości, ponieważ nie określa ona jaką osobę należy uznać za migranta, a jaką nie. Ponadto mobilnośćc ludzi jest zjawiskiem złożonym, wynikającym z wielu czynników ekonomicznych, politycznych i społecznych.

Wieloaspektowość zjawiska wpływa na brak możliwości ustalenia jednolitej teorii objaśniającej, dlaczego ludzie migrują i w jaki sposób decydują o wyborze kierunku migracji. Już w XVIII wieku Adam Smith w swoich pracach poruszał ekonomiczne kwestie migracji (Smith, 2007, s. 153). Przez kolejne lata uwaga naukowców skupiała się na tworzeniu teorii analizujących zjawisko mobilności społeczeństwa, biorąc pod uwagę różne czynniki, motywy i bodźce. Jako wynik analizy zjawiska powstawały teorie migracji: teoria push-pull, zaproponowana przez Everetta S. Lee w 1966 roku; neoklasyczna teoria kapitału ludzkiego autorstwa Larego A. Sjaastada; teoria dualnego rynku pracy przedstawiona w 1969 roku przez Michaela J. Piore; teoria etnicznej enklawy na rynku pracy opublikowana w 1985 roku przez Alejandro Portesa i Roberta L. Bacha; teoria nowej ekonomii migracji zainicjowana pracami Odeda Starka i Davida E. Blooma oraz wiele innych, powstałych dzięki zmienności otoczenia, rozwojowi gospodarek i sytuacjom politycznym.

Przytoczone powyżej teorie odnoszą się do mechanizmów rynkowych, które analizują stronę popytową i podażową zjawiska. Podjęte w teoriach migracji rozważania skupiają się na migracjach zarobkowych, nie uwzględniając na przykład migracji przymusowych. Nie mniej jednak, poddając dogłębnej analizie różnego rodzaju ruchy ludności, czynniki ekonomiczne są jednym z elementów procesu decyzyjnego. Ponadto żadna z teorii nie bierze pod uwagę istotnego czynnika kształtującego skalę i strukturę migracji, jakim jest polityka migracyjna będąca szansą albo barierą dla cudzoziemców. Strategia taka powinna zawierać zasady i działania państwa w odniesieniu do migracji, czyli uwzględnić najważniejsze grupy interesów, do których zalicza się: chęć

\footnotetext{
2 W artykule zamiennie stosuje się pojęcia mobilność i migracja.
} 
podtrzymania wzrostu rozwoju gospodarczego, dążenie do zapewnienia bezpieczeństwa kraju oraz utrzymania tożsamości narodowej. I tak na przykład uproszczone procedury uzyskania pozwolenia na pracę lub pobyt stają się nie tylko zachętą dla migrantów zarobkowych do przyjazdu, ale również stwarzają przedsiębiorstwom optymalne warunki rozwoju, umożliwiając uzupełnienie luk kadrowych.

Rozwój przedsiębiorstw krajowych pozytywnie wpływa na sytuację gospodarczą państwa, która determinuje skalę ruchów migracyjnych. Według danych Międzynarodowej Agencji Pracy głównym kierunkiem migracji zarobkowych są kraje rozwinięte. W 2017 roku spośród 164 mln migrantów ekonomicznych 111,2 mln, czyli 67,9\% cudzoziemców pracowało w państwach o wysokim dochodzie. Przedstawione liczby potwierdzają założenia teorii migracji, która mówi o tym, że imigranci zarobkowi wybierają regiony, gdzie jest możliwa poprawa sytuacji finansowej. W tym przypadku zyskuje nie tylko osoba zmieniająca miejsce stałego zamieszkania, ale również kraj przyjmujący. Międzynarodowe migracje ekonomiczne pozwalają na lepszą, bardziej optymalną alokację zasobów pracy, tj. kierują się one tam, gdzie jest możliwość uzyskania wyższej stopy wzrostu (Piekutowska, 2019, s. 56). Przedstawione twierdzenie powinno być brane pod uwagę podczas opracowywania polityki migracyjnej każdego państwa, jak również sytuacja demograficzna, ekonomiczna oraz interesy przedsiębiorstw i sytuacja na krajowym rynku pracy.

Niedobór pracowników w Polsce jest jednym z głównych tematów interesujących polityków, przedsiębiorców i media. Na rynku krajowym obserwuje się tendencję niezaspokojonego popytu na pracę oraz deficyt konkretnych kompetencji i umiejętności, co jest bardziej odczuwalne po wejściu Polski do Unii Europejskiej w 2004 roku. Przedsiębiorstwa coraz częściej deklarują zarówno brak dostępności specjalistów, jak i pracowników do prac prostych. Wraz ze zmianami politycznymi, rozwojem gospodarczym oraz postępem technologicznym zmieniają się podejścia przedsiębiorstw do doboru pracowników. Przez pracodawców są bardzo cenione wiedza, umiejętności, kreatywność oraz

${ }^{3}$ W Polsce zgodnie z $\$ 1$ pkt 20 rozporządzenia Ministra Pracy i Polityki Społecznej z dnia 21 kwietnia 2015 r. w sprawie przypadków, w których powierzenie wykonywania pracy cudzoziemcowi pochodzącego z Armenii, Białorusi, Gruzji, Mołdawii, Rosji, Ukrainy na terytorium Rzeczypospolitej Polskiej jest dopuszczalne zatrudnianie tych obywateli bez konieczności uzyskania zezwolenia na pracę, czyli na podstawie tzw. uproszczonej procedury zatrudniania. Należy też wziąć pod uwagę osoby, które zgodnie z ustawą z dnia 7 września 2007 r. o Karcie Polaka są zwolnieni z obowiązku posiadania zezwolenia na pracę i mogą pracować na takich zasadach, jak obywatele polscy. 
innowacyjność, które wpływają na rozwój firm. Tak więc, zasoby ludzkie stają się coraz istotniejszym czynnikiem oddziałującym na funkcjonowanie organizacji.

Problemy kadrowe wielu przedsiębiorstw wynikają, m.in. z niedopasowania kwalifikacji pracowników do potrzeb rynku, niżu demograficznego, salda migracji oraz bezrobocia dobrowolnego. $\mathrm{W}$ tej sytuacji istotne jest podjęcie takich działań, które zmniejszą skutki niedoboru pracowników oraz związane z tym koszty. Wpływ zjawiska niezaspokojonego popytu na pracę potwierdza rozwijający się kierunek kształcenia specjalistów ds. zarządzania zasobami ludzkimi oraz sektor doradztwa personalnego, związany z pozyskiwaniem pracowników. Należy zaznaczyć, że zwiększone zapotrzebowanie na siłę roboczą powoduje powstanie nowych form przekazywania informacji o rekrutacji (targi pracy, w tym zagraniczne; bilbordy, np. na przystankach autobusowych; reklamy na środkach transportu; tematyczne grupy w sieciach społecznościowych). Pozyskiwanie pracowników nie ograniczają się już tylko do lokalnego lub ogólnokrajowego rynku pracy, lecz obszar poszukiwań zasobów ludzkich odbywa się również w skali międzynarodowej. Deficyty kadrowe na rynku pracy zachęcają firmy do rekrutacji cudzoziemców, gdyż zjawisko niezaspokojonego popytu na pracę wiąże się z ponoszeniem kosztów nie tylko w zakresie dodatkowej aktywności departamentu kadr, ale również związanych z trudnościami w funkcjonowaniu organizacji, mogących wynikać z przestojów w pracy lub opóźnień w realizacji zamówień i dostaw.

\section{Rynek pracy w Polsce}

W 2018 roku w Polsce działało 2 150,3 tys. przedsiębiorstw niefinansowych, podczas gdy w 2017 roku ta liczba wynosiła 2 077,0 tys., czyli nastąpił wzrost o 3,5\%. W przeciągu dziesięciu lat liczba przedsiębiorstw wzrosła o ponad $15 \%$, co przedstawia wykres 1 . 
Wykres 1. Liczba przedsiębiorstw aktywnych w Polsce w latach 2008-2017 (w tys.)

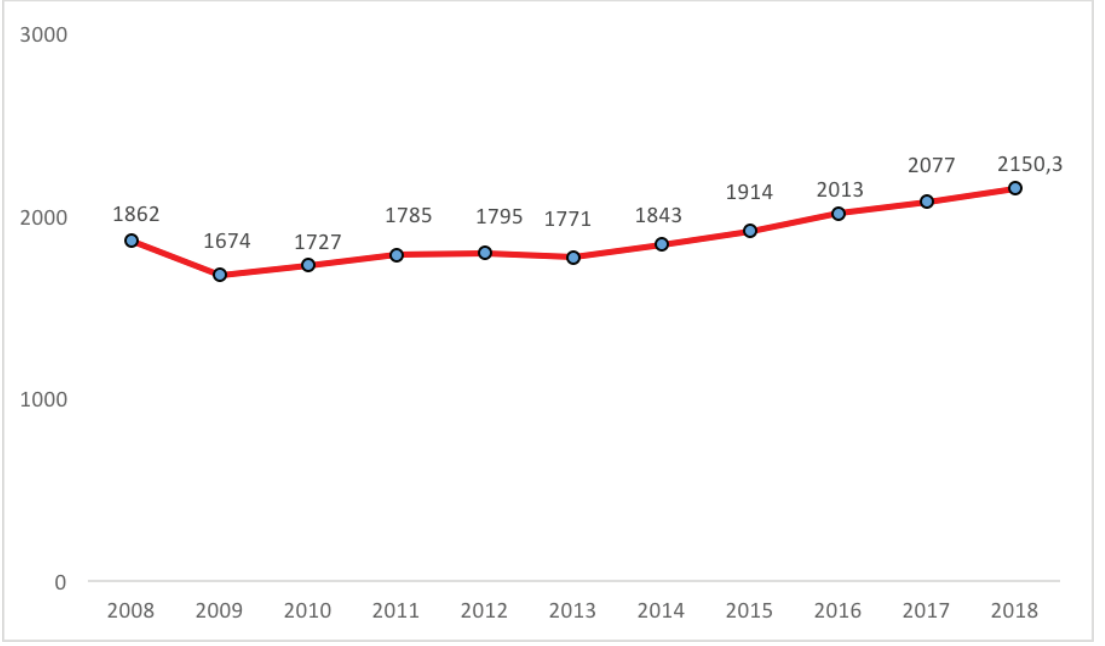

Źródło: opracowanie własne na podstawie publikacji GUS o działalności przedsiębiorstw niefinansowych z lat 2009-2020.

Wśród wszystkich przedsiębiorstw w 2018 roku dominowały jednostki micro (96,7\%). Pozostałe kategorie małych, średnich i dużych przedsiębiorstw stanowiły odpowiednio 2,4\%, 0,7\% i 0,2\% wszystkich aktywnych firm. Najliczniejszą grupą przedsiębiorstw były jednostki handlowe $(23,6 \%)$, a następnie przedsiębiorstwa sektora budownictwa (14\%). Działalność profesjonalną, naukową i techniczną prowadziło 13,6\% przedsiębiorstw, a działalność przemysłową - 10,4\%.

Na podstawie danych Głównego Urzędu Statystyczne (GUS) niefinansowe podmioty gospodarcze w 2019 roku zanotowały wzrost wyników finansowych w porównaniu do 2018 roku. Przychody z całokształtu działalności były wyższe o 5,8\% od uzyskanych rok wcześniej. W analizie działalności przedsiębiorstw niefinansowych w Polsce warto zaznaczyć, że wynik finansowy ze sprzedaży produktów, towarów i materiałów wyniósł 144,0 mld zł i był wyższy niż w roku 2018 o 4,6\%. Wynik finansowy z pozostałej działalności operacyjnej ukształtował się na poziomie 4,2 mld zł i był wyższy o $0,7 \mathrm{mld}$ zł niż przed rokiem.

W przedsiębiorstwach niefinansowych według stanu na 31 grudnia 2018 roku pracowało prawie $10 \mathrm{mln}$ osób. W porównaniu do okresu poprzedniego w Polsce zanotowano wzrost zatrudnienia o 1,4\%. Należy zaznaczyć, że od 2013 liczba osób zatrudnionych w sektorze przedsiębiorstw niefinansowych nieprzerwanie rośnie, co obrazuje wykres 2. 
Wykres 2. Liczba pracujących w sektorze przedsiębiorstw w latach 2008-2018

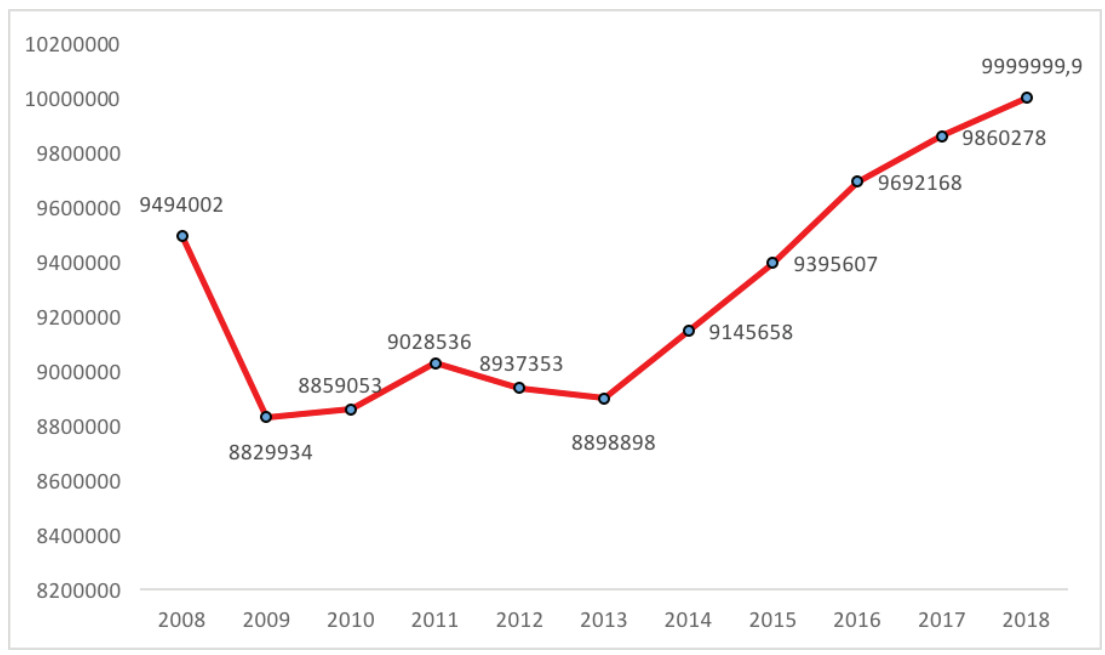

Źródło: opracowanie własne na podstawie publikacji GUS o działalności przedsiębiorstw niefinansowych $\mathrm{z}$ lat 2009-2020.

Interesujący okazuje się fakt, że w III kwartale 2019 roku liczba osób aktywnych zawodowo w wieku 15 lat i więcej wynosiła 17151 tys., czyli o 0,7\% mniej w stosunku do poprzedniego okresu. Populacja biernych zawodowo w wieku 15 lat i więcej w wyżej wskazanym okresie wyniosła 13124 tys. osób, a w analogicznym okresie 2018 roku liczba ta była o 15 tys. większa. Oznacza to, że liczba biernych zawodowo w wieku 15 lat i więcej w III kwartale 2019 roku spadła o 0,1\%. Na podstawie danych GUS współczynnik aktywności zawodowej Polaków w porównaniu do poprzedniego okresu spadł o $0,1 \%$ badanej populacji, czyli do 56,7\%. Liczba biernych zawodowo w 2019 roku wyniosła 13124 tys. i stanowiła 43,4\% ludności w wieku ponad 15 lat. Na koniec IV kwartału 2019 roku liczba wolnych miejsc pracy w Polsce wynosiła 125,4 tys., co stanowiło 11\% mniej w porównaniu do IV kwartału 2018 roku. Natomiast w IV kwartale 2019 zlikwidowano o 16,3\% miejsc pracy mniej niż w IV kwartale 2018 roku (zob. wykres 3). 


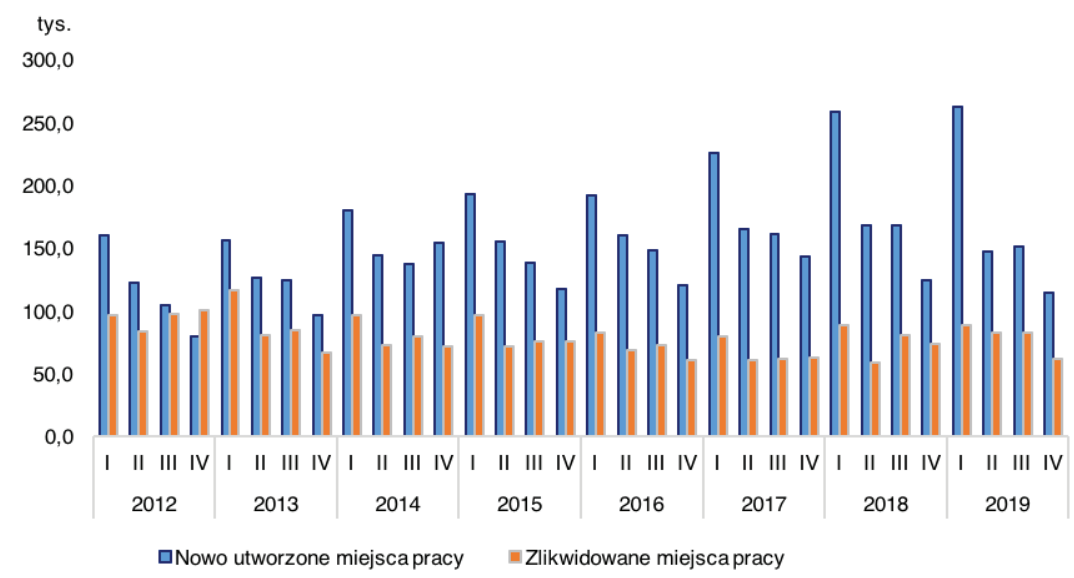

Źródło: opracowanie własne na podstawie publikacji GUS Popyt na pracę w 2019 roku.

Analiza wykresu 3. dowodzi, że wzrost lub spadek liczby miejsc pracy jest skorelowany z sytuacją gospodarczą oraz wynika ze wzrostu liczby przedsiębiorstw na polskim rynku. Rynek pracy ma też charakter sezonowy, co obrazuje wykres 3. Największa liczba nowych miejsc pracy przypada na pierwsze kwartały, natomiast czwarte kwartały cechuje spadek ilości nowych etatów. Od 2013 roku rośnie też liczba przedsiębiorstw niefinansowych działających na rynku polskim, co pociąga za sobą stabilny wzrost ilości nowych miejsc pracy.

Na koniec IV kwartału 2019 roku Polska odczuwała niedobór pracowników. Niezaspokojony popyt stanowił ponad 125 tys. jednostek siły roboczej, z tego około 106 tys. miejsc pracy w sektorze prywatnym. Największy niedobór pracowników został odnotowany w sektorze przetwórstwa przemysłowego (około 27 tys. jednostek siły roboczej), w budownictwie (20 tys.) i handlu (19 tys.). $\mathrm{W}$ analizowanym okresie największe zapotrzebowanie było na robotników przemysłowych i rzemieślników (około 28 tys.), różnego rodzaju specjalistów (około 24 tys.), operatorów i monterów maszyn i urządzeń (20 tys.) i pracowników usług oraz sprzedawców (wykres 4). 
Wykres 4. Liczba wolnych miejsc pracy w Polsce według zawodów na koniec IV kwartału 2019 roku (w tys.)

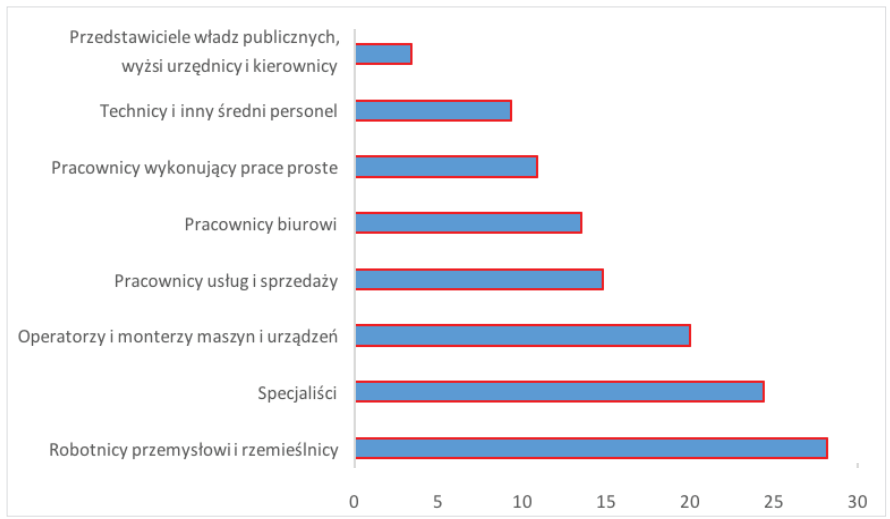

Źródło: opracowanie własne na podstawie publikacji GUS Popyt na pracę w 2019 roku.

Na koniec IV kwartału 2019 roku największe zapotrzebowanie na siłę roboczą odczuwały województwa: mazowieckie (35,4 tys.), śląskie (16,4 tys.) oraz małopolskie (13,6 tys.). W mniejszym stopniu deficyt odczuły województwa lubelskie (1,7 tys.), podlaskie (2,0 tys.) i świętokrzyskie (2,0 tys.).

W związku ze wzrostem liczby przedsiębiorstw oraz rosnącym popytem na pracę, migracja zarobkowa staje się dziś źródłem siły roboczej dla wielu państw. Według danych Urzędu do Spraw Cudzoziemców (UdSC) na początku 2020 roku około 423 tys. imigrantów posiadało ważne zezwolenia na pobyt w Polsce - liczba ta zwiększyła się o 50 tys. nowych osób w przeciągu 2019 roku. Większość imigrantów stanowili obywatele Ukrainy, Białorusi oraz Gruzji, w tym ponad połowa cudzoziemców posiadających pozwolenia na pobyt stały są to osoby w przedziale wiekowym 20-39 lat. Zwiększony napływ imigrantów jest spowodowany wzrostem gospodarczym w Polsce, rozwojem przedsiębiorstw oraz uproszczonymi warunkami prawnymi umożliwiającymi legalne wykonywanie pracy ${ }^{4}$. W roku

4 Zezwolenie na pracę w Polsce nie jest wymagane m.in. gdy cudzoziemiec: posiada status członka rodziny obywatela UE/EOG/Szwajcarii, korzysta w Polsce z ochrony międzynarodowej (posiada status uchodźcy, korzysta z ochrony uzupełniającej), posiada zezwolenie na pobyt stały w Rzeczypospolitej Polskiej, posiada zezwolenie na pobyt rezydenta długoterminowego Unii Europejskiej w Rzeczypospolitej Polskiej, posiada zgodę na pobyt ze względów humanitarnych, posiada zgodę na pobyt tolerowany w Rzeczypospolitej Polskiej, jest małżonkiem obywatela polskiego, posiadający zezwolenie na pobyt czasowy na terytorium Rzeczypospolitej Polskiej udzielone w związku z zawarciem związku małżeńskiego, posiada zezwolenie na pobyt czasowy w celu połączenia się z rodziną, zezwolenie na pobyt czasowy w celu kształcenia się na studiach, posiada ważną Kartę Polaka, jest absolwentem polskich szkół ponadgimnazjalnych, stacjonarnych studiów wyższych lub stacjonarnych studiów doktoranckich na polskich uczelniach (Urząd do Spraw Cudzoziemców, 2020). 
2019 zostało wydanych 444 tys. zezwoleń na pracę dla cudzoziemców, co stanowi wzrost o ponad 115 tys. w stosunku do roku 2018 (wykres 5).

Wykres 5. Liczba wydanych zezwoleń na pracę oraz zmiany procentowe w latach 2010-2019

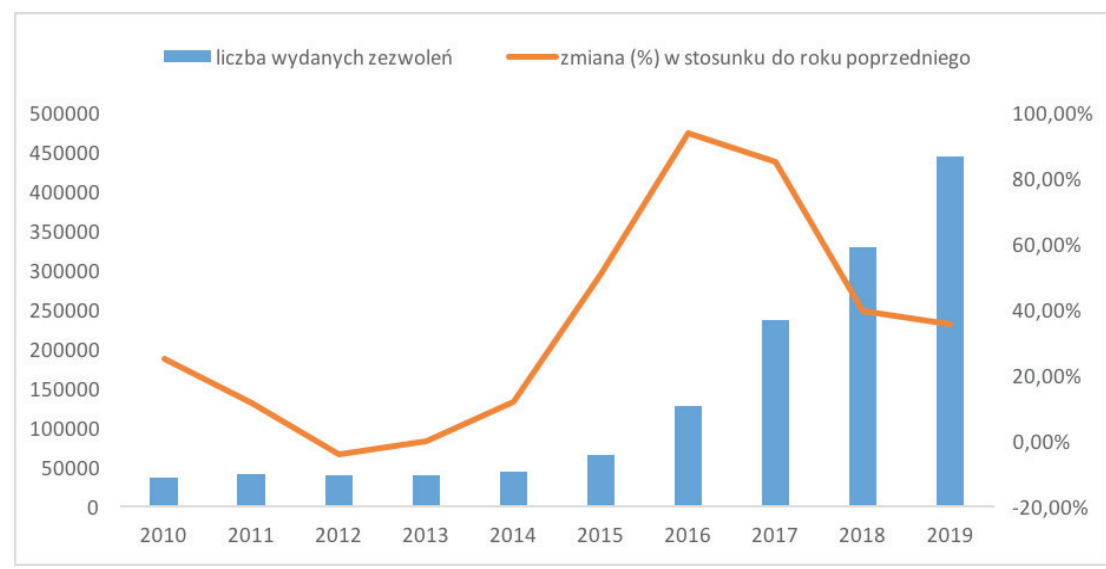

Źródło: opracowanie własne na podstawie danych Ministerstwa Rodziny, Pracy i Polityki Społecznej.

W roku 2019 w Polsce zarejestrowano o 3\% więcej oświadczeń dotyczących zamiaru powierzenia wykonywania pracy cudzoziemcom w stosunku do 2018 roku. Z raportu Ministerstwa Rodziny, Pracy i Polityki Społecznej (MRPiPS) wynika, że 97 tys. pracodawców zarejestrowało chęć powierzenia pracy cudzoziemcowi. Wśród wszystkich cudzoziemców, którym zamierzano powierzyć pracę w 2019 roku zdecydowaną większość stanowili Ukraińcy (89,24\%). Pozostałe osoby stanowili obywatele Białorusi (4,54\%), Armenii (0,17\%), Gruzji (2,7\%), Mołdawii (2,56\%) oraz Rosji (0,79\%). Pracodawcy, rejestrując oświadczenia w 2019 roku, najczęściej deklarowali zatrudnienie cudzoziemca na podstawie umowy zlecenia (około $1 \mathrm{mln}$ ), na podstawie umowy o pracę (451 tys.) i umowy o dzieło (32 tys.).

W 2019 roku największe zapotrzebowanie na pracowników zagranicznych zgłosiły podmioty działające w sektorze przetwórstwa przemysłowego (zgłoszono ponad 600 tys. oświadczeń) oraz budownictwa (322 tys. oświadczeń). Polscy pracodawcy w 2019 roku zamierzali powierzyć wykonywanie pracy cudzoziemcom przy pracach prostych (zgłoszono ponad 800 tys. oświadczeń), robotnikom przemysłowym i rzemieślnikom (396 tys. oświadczeń), specjalistom (10 tys. oświadczeń), co obrazuje wykres 6. 
Wykres 6. Liczba oświadczeń dotyczących zamiaru powierzenia wykonywania pracy cudzoziemcom według zawodów w 2019 roku

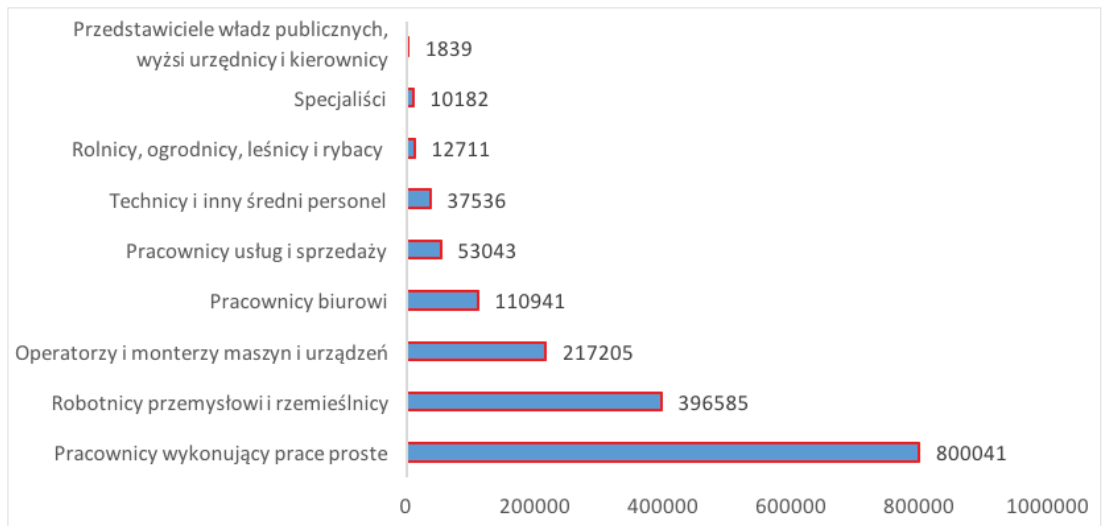

Źródło: opracowanie własne na podstawie publikacji GUS Popyt na pracę w 2019 roku.

\section{Migracja zarobkowa jako narzędzie zaspokojenia popytu na pracę przez polskie przedsiębiorstwa}

Przedstawione dane przez UdSC oraz MRPiPS pozwalają stwierdzić, że imigranci przyczyniają się do kształtowania rynku pracy w Polsce, a popyt zgłaszany przez polskich pracodawców jest coraz większy. Skalę, dynamikę i strukturę migracji można uznać za swojego rodzaju wskaźnik odzwierciedlający poziom rozwoju gospodarki państwa (Yakshibaeva, 2017, s. 1215-1223).

W celu odpowiedzi na pytanie na ile zatrudnienie pracowników wynika z braku możliwości znalezienia polskich pracowników, a na ile ze strategii biznesowej firm, zastosowano jedną z metod badań socjologicznych, tj. jest pogłębiony wywiad indywidualny składający się z pytań otwartych. Ponadto celem badania było otrzymanie wiedzy na temat wizerunku pracowników zagranicznych, zatrudnionych w polskich firmach. Po przeprowadzonym badaniu pilotażowym, próbą badawczą zostało objętych 89 jednostek ${ }^{5}$ zatrudniających imigrantów. Wybrane firmy należą do grupy małych i średnich przedsiębiorstw z różnych sektorów działalności gospodarczej. Wśród nich są firmy produkcyjne, handlowe, usługowe i budowlane, co obrazuje wykres 7.

5 Badania zostały przeprowadzone w okresie od grudnia 2019 roku do lutego 2020 roku. 
Wykres 7. Branże badanych przedsiębiorstw

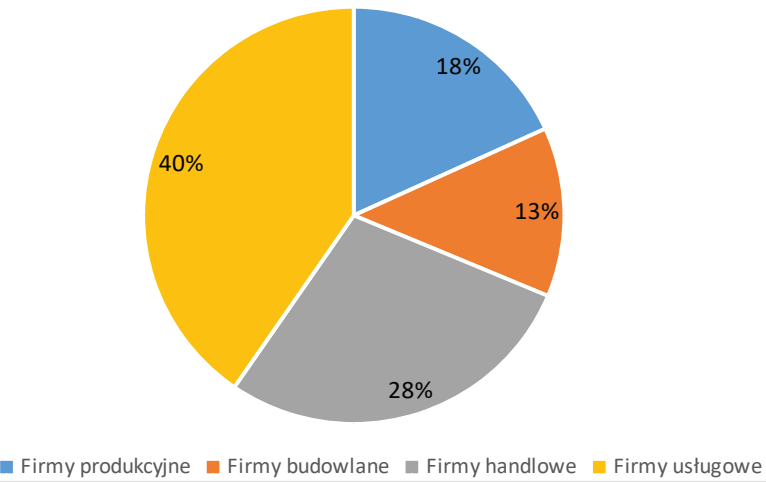

Źródło: opracowanie własne.

Wśród badanych przedsiębiorstw aż 62\% ma problemy z zatrudnieniem odpowiednich pracowników na różnych stanowiskach pracy. W sposób pośredni to negatywne zjawisko odczuwa $13 \%$ badanych firm, ponieważ partnerzy biznesowi mają trudności w znalezieniu kandydatów na wolne stanowiska. Tylko 6\% przedsiębiorstw nie odczuwa problemu braku pracowników. Natomiast 19\% badanych spodziewa się takiego problemu w przyszłości.

Wykres 8. Odczuwalność braku pracowników w badanych przedsiębiorstwach

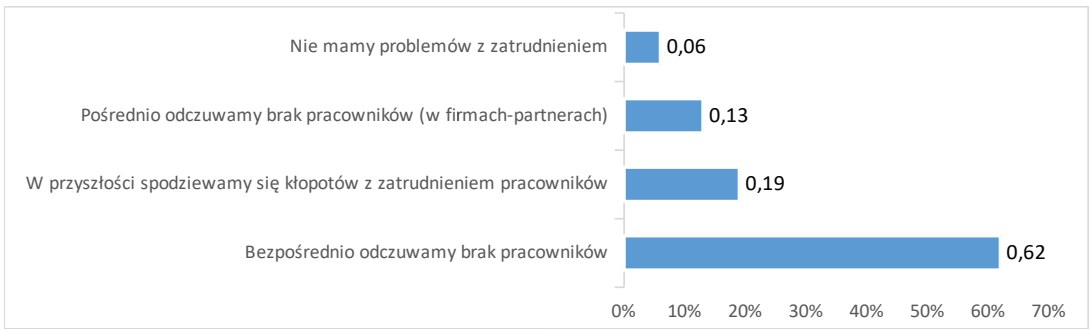

Źródło: opracowanie własne.

W związku z deklarowaną niemożnością zaspokojenia popytu na pracę $46 \%$ badanych przedsiębiorstw zamierza lub już wdrożyło procedury w celu wyeliminowania tego problemu i ograniczenia wywołanych przez niego negatywnych skutków. Wśród tych działań firmy wymieniły następujące czynności:

- nawiązanie współpracy z agencjami specjalizującymi się w pozyskiwaniu pracowników, w tym zagranicznych,

- $\quad$ wprowadzenie w przedsiębiorstwie dla pracowników systemu benefitów za polecenie kandydata do pracy,

- uproszczenie procesu rekrutacji, 
- wprowadzenie dodatkowych benefitów dla imigrantów (zapewnienie noclegów, ubezpieczenie społeczne, pokrycie kosztów podróży oraz wsparcie w procesie pozyskania pozwolenia na pracę).

Przedsiębiorstwa coraz częściej decydują się na poszukiwanie pracowników na zagranicznych rynkach pracy oraz wśród imigrantów, przez co cudzoziemcy mają szansę na zatrudnienie zarówno na stanowiskach niewymagające specjalnych kwalifikacji, jak i specjalistycznych oraz kierowniczych. Ponadto podczas badania respondenci wskazali, że na niektóre rodzaje stanowisk preferują zatrudnianie cudzoziemców.

W kolejnym pytaniu dotyczącym preferowanych narodowości zatrudnianych cudzoziemców aż $65 \%$ respondentów skłonnych było zatrudnić osoby z Białorusi, Ukrainy lub Rosji z uwagi na bliskość kulturową i językową. Około 12\% wyraziło zainteresowanie innymi narodowościami, a dla 23\% badanych obywatelstwo pracownika nie miało żadnego znaczenia.

Z przeprowadzonych badań wynika, że nie tylko narodowość pracownika ma znaczenia dla potencjalnego pracodawcy, ale też wykształcenie, umiejętności oraz koszty zatrudnienia pracownika. W badanych przedsiębiorstwach najbardziej brakowało specjalistów ze znajomością języków obcych i rynków zagranicznych, programistów, inżynierów oraz pracowników do prac prostych. Polscy pracodawcy na stanowiska związane z wykonywaniem prac prostych preferują zatrudnić cudzoziemców - taka odpowiedź była charakterystyczna dla 80\% respondentów. Ich zdaniem imigranci zarobkowi są skłonni podjąć pracę za niższe wynagrodzenie niż obywatele Polski. W rezultacie przedsiębiorcy, pozyskując niższym kosztem kapitał ludzki, uzyskują możliwość optymalizacji kosztów działalności przedsiębiorstwa.

Z badań wynika również, że imigranci zarobkowi mogą liczyć na prace odpowiadające ich preferencjom. Zdaniem $22 \%$ badanych zatrudnieni imigranci posiadają specjalistyczną wiedzę, której nie zapewnia polski system edukacji, dlatego są bardziej atrakcyjnymi kandydatami na polskim rynku pracy. Ponadto respondenci jako przyczynę zatrudniania cudzoziemców wskazywali też na posiadaną wiedzę i umiejętności - należy przez to rozumieć np. znajomość języków obcych (zatrudnianie do obsługi klientów zagranicznych) lub wiedza na temat rynków zagranicznych, z którymi firma posiada relacje lub planuje je nawiązać. Poprzez zatrudnianie cudzoziemców pracodawcy optymalizują strukturę firmy pod względem wykształcenia, umiejętności i doświadczenia, co może pozytywnie wpłynąć na funkcjonowanie przedsiębiorstwa.

W przeprowadzonym badaniu zapytano także o motywy decydujące o zatrudnieniu imigrantów. Jako główny powód zatrudniania cudzoziemców był 
wskazywany fakt, że polscy kandydaci żądają wyższego wynagrodzenia niż imigranci zarobkowi, którzy nie stawiają zbyt wysokich oczekiwań zarobkowych, gdyż na początku mogą liczyć na ponad dwukrotnie większe wynagrodzenie niż w kraju ojczystym.

Uzupełnienie braków kadrowych oraz zapewnienie ciągłości produkcji, to kolejny powód zatrudnienia cudzoziemców. W sytuacjach gdy na rynku lokalnym istnieją nieobsadzone stanowiska pracy oraz brakuje odpowiednio wykwalifikowanych i przeszkolonych kandydatów, przedsiębiorcy decydują się na zatrudnienie imigrantów, ponieważ w taki sposób uzupełniają na bieżąco niedobory kadrowe w przedsiębiorstwie.

Dla badanych przedsiębiorstw, zwłaszcza w branży budowlanej oraz usługowej, jednym z głównych argumentów przemawiającym za zatrudnieniem obcokrajowca jest możliwość powierzenia zadań w dni wolne od pracy i święta. Imigranci zarobkowi są w stanie wykonywać swoją pracę nie tylko w podstawowym zakresie, ale również angażować się w dodatkowe projekty w ramach nadgodzin oraz w dni wolne od pracy (taki tryb pracy jest postrzegany przez nich jako szansa, a nie zło konieczne).

Odpowiedzi na pytania polskich pracodawców pozwalają na stwierdzenie, że zatrudnienie imigrantów uzupełnia niedobór powstały na polskim rynku pracy i ma charakter komplementarny. Wśród ankietowanych przedsiębiorców 90\% zaznaczyło, że dzięki obcokrajowcom udało im się utrzymać stabilność zatrudnienia i produkcji. Respondenci wskazywali również, że cudzoziemcy pozytywnie wpływają na rozwój przedsiębiorstw.

Polskie firmy coraz częściej deklarują chęć zatrudnienia imigrantów, co potwierdza rosnąca liczba składanych oświadczeń dotyczących zamiaru powierzenia wykonywania pracy cudzoziemcom oraz opinia pracodawców. W wywiadzie respondenci wskazali na jeszcze jeden pozytywny faktor przyczyniający się do poprawy finansowej przedsiębiorstw, tj. wprowadzanie - w związku z dużym napływem imigrantów - dodatkowych usług i produktów dla obcokrajowców, przez co firmy zwiększają swoje portfolio oraz dochody.

\section{Zakończenie}

W Polsce utrzymuje się tendencja wzrostowa zatrudniania cudzoziemców, gdyż coraz więcej branż, głównie przetwórstwa przemysłowego, budownictwa i handlu, wyraża zapotrzebowanie na zagranicznych pracowników. Przez zatrudnienie obcokrajowców polskie przedsiębiorstwa uzupełniają braki ka- 
drowe, zyskują niskim kosztem cenny potencjał zagranicznych pracowników, co przekłada się nie tylko na ich rozwój, ale i konkurencyjność na lokalnym i międzynarodowym rynku. Polskich pracodawców interesują najbardziej osoby gotowe do pracy w tych obszarach gospodarki, w których brakuje lokalnych specjalistów lub miejscowi pracownicy nie chcą pracować ze względu na niskie wynagrodzenie. Imigracja staje się głównym narzędziem do zrównoważenia rynku pracy w Polsce oraz zapewnienia ciągłości operacyjnej przedsiębiorstw. Mobilność społeczeństwa nie tylko uzupełnia braki kadrowe, ale również daje znaczący impuls do rozwoju i poprawy sytuacji finansowej polskich firm, m.in. przez zapewnienie dopływu nowej wiedzy i umiejętności oraz pobudzenie poziomu konsumpcji na rynku.

Wprowadzenie w Polsce stanu zagrożenie epidemicznego w związku z pandemią koronowirusa SARS-CoV-2, wywołującego chorobę COVID 19, diametralnie zmieniło sytuację na polskim rynku pracy. Wprowadzone obostrzenia spowodowały, że wiele przedsiębiorstw ograniczyło produkcję, a część z nich, zwłaszcza w sektorze usługowym, zawiesiło działalność. Niepewna sytuacja gospodarcza wymusiła na firmach nie tylko zmniejszenie wynagrodzenia, ale również redukcję etatów. Spowodowało to, że wielu imigrantów zatrudnionych w polskich firmach wyjechało do swoich krajów. Jednak stopniowe odmrażanie gospodarki powoduje, że wielu firmom, głównie budowlanym i rolnym, zaczyna brakować pracowników, przede wszystkim z innych państw. Powstaje jednak pytanie, jak będzie wyglądała struktura zatrudnienia w momencie całkowitego odmrożenia gospodarki polskiej? Czy przedsiębiorstwa wciąż będą potrzebować imigrantów? Tak niestandardowa i nieoczekiwana sytuacja na rynku stanowi istotną przesłankę do kontynuacji badań nad strukturą zatrudnienia oraz sposobem zaspokojenia popytu na pracę na Polskim rynku pracy.

\section{Bibliografia}

Belot, M., Ederveen, S. (2012). Cultural barriers in migration between OECD countries. Journal of Population Economics, 25, 1077-1105.

Dubisz, S. (red.). (2003). Uniwersalny stownik języka polskiego. Warszawa: Wydawnictwo Naukowe PWN.

Główny Urząd Statystyczny (2020). Popyt na prace w 2019 roku. Pobrane z: https://stat. gov.pl/download/gfx/portalinformacyjny/pl/defaultaktualnosci/5820/1/15/1/ popyt_na_prace_w_2019_roku.pdf (7.09.2020).

Hicks, J. (1963). The theory of Wages ( $2^{\text {nd }}$ ed.). London: Macmillan. 
Massey, D. S., Arango, J., Hugo, G., Kouaouci, A., Pellegrino, A., \& Taylor, J. E. (1993). Theories of International Migration. A Review and Appraisal, Population and Development Review, 19(3), 431-466.

Piekutowska, A. (2019). Migracja zarobkowa i jej wpływ na rynek pracy. Warszawa: CeDeWu.

Ravenstain, E. G. (1889). The Laws of Migration. Second Paper. Wiley of the Royal Statistical Society, 52(2), 241-305.

Smith, A. (2007). An Inquiry into the Nature and Causes of the Wealth of Nations. Lausanne: MetaLibri Digital Library. Retrieved from http://www.ibiblio.org/ml/ libri/s/SmithA_WealthNations_s.pdf (7.08.2020).

Stark, O., \& Bloom, D. E. (1985). The New Economics of Labour Migration. The American Economic Review, 75(2), 173-178.

Stark, O., \& Lucas, R. E. B. (1988). Migration, Remittances, and Family. Economic Development and Cultural Change, 36(3), 465-481.

United Nations Development Programme (2003), Making Global Trade Work for People, New York: Earthscan Publications Ltd.

Urząd do Spraw Cudzoziemców (2020). Cudzoziemcy w Polsce po 2019 roku. Pobrane z: https://udsc.gov.pl/legalizacja-pobytu-w-2019-r-podsumowanie/ (10.04.2020).

Yakshibaeva, G. V. (2017). Analysis of the dynamics and structure of labor migration in the region. Journal of Economy and Entrepreneurship, 8(3), 1215-1223.

Zakrzewski, R., Skowrońska, A. (red.). (2019). Raport o stanie sektora małych i średnich przedsiębiorstw w Polsce. Warszawa: Polska Agencja Rozwoju Przedsiębiorczości. Pobrane z: https://www.parp.gov.pl/storage/publications/pdf/2019_07_ROSS. pdf (10.04.2020).

\section{Streszczenie}

Niedobór pracowników w gospodarce jest zjawiskiem coraz bardziej zauważalnym w krajach rozwiniętych. Wielu przedsiębiorstwów ma trudności z rekrutacją pracowników z krajowego rynku pracy, co wiąże się ze zmianami demograficznymi oraz niedopasowaniem szkolnictwa do wymogów rynku. Rozwiązaniem problemu jest zatrudnianie pracowników z innych krajów, dlatego celem artykułu było przedstawianie, że zatrudnienie imigrantów zarobkowych stanowi jedną z dróg pozyskania pracowników. W pierwszej części artykułu omówiono wpływ migracji na rynek pracy. Następnie przedstawiono sytuację na polskim rynku pracy. Zaprezentowano także dane dotyczące zatrudnienia cudzoziemców w Polsce oraz wyniki badań przeprowadzonych wśród polskich przedsiębiorców na temat zatrudniania imigrantów.

SŁowA KLUCzowE: migracje, migracje zarobkowe, zatrudnianie cudzoziemców, przedsiębiorstwo. 


\section{Summary}

The shortage of employees in the economy is a phenomenon that is becoming more and more noticeable in developed countries. Many enterprises find it increasingly difficult to recruit employees from the domestic labor market, which is related to demographic changes and the mismatch between education system and market requirements. The solution to the problem is the employment of employees from other countries. Therefore the purpose of the article is to show that the employment of economic immigrants is one of many solutions to the problem of staff recruitment. The first part of the article discusses the impact of migration on labor market. Then the situation on the Polish labor market is presented. The final part of the article presents data on the employment of foreigners in Poland and the results of research conducted among Polish entrepreneurs on the employment of immigrants.

KEYWORDs: migrations, labor migrations, employment of foreigners, enterprise.

\section{Nota o autorach}

Marta Kruhlaya - mgr; doktorantka w Kolegium Nauk o Przedsiębiorstwie Szkoły Głównej Handlowej w Warszawie; główne obszary zainteresowań naukowych: migracja obywateli państw z obszaru byłego ZSSR do Polski, zarządzanie zasobami ludzkimi w ujęciu branżowym; mkruhlaya@gmail.com; ORCID: 0000-0003-1478-0557.

Marcin Molenda - dr; Kolegium Nauk o Przedsiębiorstwie Szkoły Głównej Handlowej w Warszawie; główne obszary działalności naukowej: zarządzanie zasobami ludzkimi w przedsiębiorstwie; mmolen@sgh.waw.pl; ORCID: 0000-0001-6566-7103. 